\title{
A model for occupational stress amongst paediatric and adult critical care staff during COVID-19 pandemic
}

\author{
T. Feeley ${ }^{1}$ (I) R. ffrench-O'Carroll ${ }^{2} \cdot$ M. H. Tan ${ }^{3} \cdot$ C. Magner ${ }^{4} \cdot$ K. L'Estrange $^{3} \cdot$ E. O'Rathallaigh $^{5} \cdot$ S. Whelan ${ }^{6} \cdot$ B. Lyons $^{2}$. \\ E. O'Connor ${ }^{5}$
}

Received: 22 September 2020 / Accepted: 11 February 2021 / Published online: 25 February 2021

(c) The Author(s), under exclusive licence to Springer-Verlag GmbH, DE part of Springer Nature 2021

\begin{abstract}
Purpose The coronavirus 2019 pandemic has placed all intensive care unit (ICU) staff at increased risk of psychological distress. To date, measurement of this distress has largely been by means of validated assessment tools. We believe that qualitative data may provide a richer view of staff experiences during this pandemic.

Methods We conducted a cross-sectional, observational study using online and written questionnaires to all ICU staff which consisted of validated tools to measure psychological distress (quantitative findings) and open-ended questions with free-text boxes (qualitative findings). Here, we report our qualitative findings. We asked four questions to explore causes of stress, need for supports and barriers to accessing supports. A conventional content analysis was undertaken.

Results In total, 269 of the 408 respondents (65.9\%) gave at least one response to a free-text question. Seven overarching themes were found, which contribute to our proposed model for occupational stress amongst critical care staff. The work environment played an important role in influencing the perceived psychological impact on healthcare workers. Extra-organisational factors, which we termed the "home-work interface" and uncertainty about the future, manifested as anticipatory anxiety, had a proportionally larger influence on worker well-being than would be expected in non-pandemic conditions.

Conclusion Our findings have important implications for appropriate allocation of resources and ensuring well-being of the ICU multidisciplinary team for this and future pandemics.
\end{abstract}

Keywords Home-work interface · Pandemic · Critical care staff · Work intensification · Occupational stress · COVID-19 . Anticipatory anxiety

T. Feeley

tfeeley@adhb.govt.nz

1 Anaesthesia Department, National Women's Health, Auckland City Hospital, Level 9, 2 Park Road, Grafton, Auckland 1023, New Zealand

2 Department of Anaesthesia and Intensive Care, Children's Health Ireland at Crumlin, Dublin, Ireland

3 Paediatric Intensive Care Department, Children's Health Ireland at Crumlin, Dublin, Ireland

4 Midwifery and Health Systems, University College Dublin School of Nursing, Dublin, Ireland

5 Department of Anaesthesia and Intensive Care, St James's Hospital, Dublin, Ireland

6 Department of Anaesthesia and Intensive Care, Children's Health Ireland at Temple Street Dublin, Dublin, Ireland

\section{Introduction and objective}

Prior to the coronavirus 2019 (COVID-19) pandemic (Zhu et al. 2020; World Health Organisation 2020), Ireland had never managed a widespread national infection outbreak and critical care staff had no prior experience of working under pandemic conditions. Furthermore, Irish healthcare staff were working in an already over-burdened and underresourced health system with recognized shortages of 2590 acute care hospital beds, 190-300 critical care beds and 500 hospital consultants (IMO 2020; An Roinn Sláinte 2018).

Therefore, in addition to amplifying existing workplace shortcomings, the pandemic has exposed Irish healthcare workers to new workplace stressors. These include the fear of infection and infecting others (Cook 2020), wearing of personal protective equipment (PPE) (Hignett et al. 2020), quarantining (Huremović 2019), working beyond usual scope of practice in unfamiliar environments, and the moral 
injury of witnessing the mismatch between the health needs of patients and the capacity to address those needs (Sorbello et al. 2020; Greenberg et al. 2020). It is not surprising therefore that psychological issues have been more common in healthcare workers than in the general population during the COVID-19 pandemic (Zhang et al. 2020; Heath et al. 2020).

Internationally, there has also been early recognition of, and attempts to mitigate, the mental health impacts on healthcare workers during this crisis. Online psychological counselling services, cognitive behaviour therapy and selfhelp interventions were promptly established (Billings et al. 2020; University College London 2020; Liu et al. 2020), and international and local health organisations published resources and guidance for frontline workers and their managers (Heath et al. 2020; Intensive Care Society 2020; Williams et al. 2020; Highfield 2020). Notwithstanding these efforts, healthcare workers have been historically reluctant users of psychological supports; they are either too busy, they have concerns about confidentiality, utilise their selfreliance or they perceive a stigma utilising these supports (Brooks et al. 2011; Gerada 2008; Shanafelt et al. 2020).

To date, measurement of psychological issues related to the pandemic has largely used validated assessment tools. Qualitative data may provide a more in-depth and detailed view of staff experiences with exploration of the complex human issues during this pandemic (Shelton et al. 2014; Teti et al. 2020). It may also provide greater insights into the specific needs of staff during this challenging time.

The objective of this study therefore was to qualitatively evaluate the perceptions and experiences of intensive care staff who worked during the pandemic. We believe this to be the first qualitative analysis of the experiences of the multidisciplinary team working in both paediatric intensive care units (ICUs) and adult ICUs throughout the COVID-19 pandemic.

\section{Methods}

\section{Setting and sample}

This project was part of a larger multicentre cross-sectional, descriptive observational study in two adult ICUs and two paediatric ICUs. Data collection took place between 7 May and 12 June 2020. Qualitative and quantitative data were collected concurrently in this study. The quantitative data have been presented elsewhere (ffrench-O'Carroll et al. 2020).

All staff working within the four participating ICUs were invited to take part. This included doctors, nurses, allied health professionals, administrative staff and managerial information and communication technology staff.

\section{Survey outline}

The survey consisted of 28 questions, four of which sought free-text answers and form the basis of this qualitative study. Questions for free-text responses are shown in Table 1. A copy of the questionnaire is shown in "Appendix 1".

\section{Data analysis}

Data were analysed using conventional content analysis. (Hsieh and Shannon 2005) This method allows for derivation of codes, and subsequently themes, from the verbatim accounts of respondents. Thus, it allowed the authors to utilise the written word of the respondents to describe the range of issues experienced by the staff at the four ICUs participating in this study. All data were analysed independently by two of the three investigators (Feeley and L'Estrange or Magner), with subsequent discussion to agree on final codes and themes. Final themes were discussed by Feeley and O'Connor.

\section{Results}

\section{Participant characteristics}

A total of 408 staff (196 adult ICU, 212 paediatric ICU) from the four sites participated in this survey. In total, 269 (65.9\%) respondents gave at least one response to a free-text question, resulting in 300 free-text answers. Breakdown of response rate according to profession, location and gender is shown in Table 2. Table 3 shows the number and profession of respondents to each question.

Table 1 Questions with free-text responses

\begin{tabular}{ll}
\hline Questionnaire number & Free text questions \\
\hline Q. 23 & Are there any other factors related to the current crisis causing you stress currently? \\
Q. 26 & What other supports would you or your colleagues benefit from but are currently not provided? \\
Q. 27 & Are there any barriers or obstacles to making use of available supports? \\
Q. 28 & Do you have any other comments/information about your experiences you would like to share?
\end{tabular}


Table 2 Response rate according to profession, location, gender

\begin{tabular}{ll}
\hline Respondent category & $\begin{array}{l}\text { Number of respondents (\% of } \\
\text { total number of survey respond- } \\
\text { ents) }\end{array}$ \\
\hline Doctor & $71(17.4)$ \\
Nurse & $273(67)$ \\
Allied healthcare professional, e.g. physiotherapist, Dietician & $35(8.5)$ \\
Support staff working in critical care, e.g. health care assistants, admin- & $28(6.8)$ \\
$\quad$ istrators & $196(48)$ \\
Paediatric intensive care healthcare workers & $212(52)$ \\
Adult intensive care healthcare workers & $331(81.1)^{\#}$ \\
Female & $76(18.6)^{\#}$ \\
Male &
\end{tabular}

\#One data point missing

Table 3 Number and profession of respondents to each of the four free-text questions

\begin{tabular}{|c|c|c|}
\hline Question & $\begin{array}{l}\text { Number of respondents } \\
\text { (percentage of total survey } \\
\text { respondents) }\end{array}$ & $\begin{array}{l}\text { Numbers of respondents (\%) doc- } \\
\text { tor vs nurse vs other }\end{array}$ \\
\hline $\begin{array}{l}\text { Q. } 23 \text { Are there any other factors related to the current crisis causing you } \\
\text { stress currently? }\end{array}$ & $159(38.9)$ & $31(19.5)$ vs $104(65.5)$ vs 24 (15) \\
\hline $\begin{array}{l}\text { Q. } 26 \text { What other supports would you or your colleagues benefit from but } \\
\text { are currently not provided? }\end{array}$ & $147(36)$ & $23(15.6)$ vs $96(65.4)$ vs 28 (19) \\
\hline $\begin{array}{l}\text { Q. } 27 \text { Are there any barriers or obstacles to making use of available sup- } \\
\text { ports? }\end{array}$ & $172(42.2)$ & 31 (18) vs 119 (69.2) vs 22 (12.8) \\
\hline $\begin{array}{l}\text { Q. } 28 \text { Do you have any other comments/information about your experi- } \\
\text { ences you would like to share? }\end{array}$ & $110(27)$ & 15 (13.6) vs 76 (69.1) vs 19 (17.3) \\
\hline
\end{tabular}

\section{Themes and subthemes}

Following analysis, the qualitative data were coded to subthemes, each in turn contributing to seven overarching themes (see Table 4). Within these themes, the work environment played an important role in influencing the perceived psychological impact on healthcare workers. Issues concerning personal factors, the home-work interface and perceptions about an uncertain future also emerged in the survey responses.

\section{Environment-work structures}

\section{Team structure, senior staff guidance}

Strain in collegial relationships was evident, with "negativity in the workplace" and a "lack of teamwork from nursing managers" both receiving frequent comment. It is evident that some staff felt poorly supported, that "there was not enough staff to help" redeployed nurses. This resulted in heightened emotions, with one respondent noting their colleagues were "not coping and 'lashing out' at other staff".

\section{Availability of resources}

Respondents linked their anxiety to resource constraints: financial, clinical equipment, personal protection equipment, and staffing. A doctor noted "not (being) able to take leave or rest days, knowing if myself or a colleague get sick, it will lead to intolerable increase of workload". One nurse synopsized the prevailing concern about lack of resources, saying that the best supports they could have would be, "Clinicians, ICU beds, Staff, ICU nurses." Comments, such as "Medical preparation was excellent in ICU—staff and equipment was there," were in the minority.

\section{Time-poor staff}

Time was repeatedly given as a barrier to accessing wellbeing supports. One allied health professional stated, "(Hospital-provided) supports require you to do counselling on days off rather than on work days, means you have to think about it on days off rather than relax. Working day much too busy to do this." In addition, increased non-work commitments were a barrier to accessing available supports. 
Table 4 Overarching themes and subthemes from qualitative analysis, (+ and - ) represents both positive and negative comments

\begin{tabular}{|c|c|}
\hline Overarching theme & Subthemes \\
\hline Environment—work structures & $\begin{array}{l}\text { Team structure }(+ \text { and }-) \text {, senior staff guidance }(+ \text { and }-) \\
\text { Availability of resources } \\
\text { Time-poor staff }\end{array}$ \\
\hline Environment—social & $\begin{array}{l}\text { Communication ( }+ \text { and }-) \text {, inescapable nature of COVID communications } \\
\text { Colleague support ( }+ \text { and }- \text { ) } \\
\text { Perceived unfairness }\end{array}$ \\
\hline Environment- the nature of the work & $\begin{array}{l}\text { Altered roles } \\
\text { Quality of training } \\
\text { Moral distress_-barriers to usual practice } \\
\text { High workload }\end{array}$ \\
\hline Environment—safety & $\begin{array}{l}\text { Personal protective equipment-guidance, quality and quantity ( }+ \text { and }- \text { ) } \\
\text { Contracting COVID-19 and/or transferring COVID-19 to colleagues and family } \\
\text { Structured psychological support }\end{array}$ \\
\hline Personal & $\begin{array}{l}\text { Response to public recognition }(+ \text { and }- \text { ) } \\
\text { Stigma to seeking supports } \\
\text { Financial }\end{array}$ \\
\hline Home-work interface & $\begin{array}{l}\text { Alteration of usual stress-relieving activities/supports } \\
\text { Altered interaction with friends/family } \\
\text { Childcare and accommodation issues }\end{array}$ \\
\hline Uncertainty about the future & $\begin{array}{l}\text { Global illness trajectory } \\
\text { Social interventions } \\
\text { Government/institutional changes } \\
\text { Further redeployment to COVID-19 patient care }\end{array}$ \\
\hline
\end{tabular}

\section{Environment-social}

\section{Communication, inescapable nature of COVID-19 communications}

Respondents raised concerns about the contrast between the paucity of workplace information from hospital managers and the ubiquity of COVID-19 references from news outlets, social media and in personal discussions. For example, "staff all express frustration at lack of information or knowing what was going on," and "continuous information given via (social media) messages...you cannot fully escape it".

\section{Colleague support}

Positive collegial interactions were a useful support in the workplace. This was evidenced by responses, such as "Having supportive colleagues and getting through it together is really important. Being able to meet and talk through it all and let off steam," and "I am lucky to be working in a fantastic ICU where everyone supported each other. Manager was very good minding everyone..."

\section{Perceived unfairness}

Perceptions of unfairness were a notable source of workplace dissatisfaction and stress. One nurse commented, "Doctors/consultants/physios/dietician/pharmacists all got to avoid coming near patients, but nurses stuck for $13 \mathrm{~h} /$ day breathing in potential virus." Another nurse raised a concern about unfair clinical allocation; "same nurses (providing care for) COVID patients every time."

\section{Environment-the nature of the work}

\section{Altered roles}

Both medical and nursing staff commented on the additional burden caused by altered conditions of work. One staff nurse commenting; "I have never been so stressed in my life...I was given a patient on a ventilator and dialysis. I was so scared I would cause harm to this patient." Respondents at management grade also expressed difficulties with their altered roles, with one stating, "as a manager I find it stressful keeping everyone safe (...) I don't want staff to say I let them down or put them at risk". 


\section{Quality of training}

Medical staff expressed concern at interruption to their training and being asked to work in service provision roles rather than their allocated training areas, with commentary, such as "teaching and training (...) all stopped when COVID hit." Medical and nursing staff were concerned they had not had the required training to care for critically ill COVID-19 patients.

\section{Moral distress-barriers to usual practice}

The measures taken to reduce transmission of the virus have had unexpected consequences for many staff, "Social distancing and PPE, while completely necessary, I have found to be a barrier to providing compassionate care to parents of critically ill or end of life children."

\section{High workload}

The impact of onerous working conditions on staff health and safety was evident from comments from all members of the multidisciplinary team. The cognitive impact of the workload prompted one nurse to suggest a "mental health day—not sick leave day". A doctor explained; "Working hours for doctors are long-you get to a point of exhaustion and burnout."

\section{Environment-safety}

\section{Personal protection equipment-guidance, quality and quantity}

PPE issues were prominent in the survey responses. It was uncomfortable ("wearing the painful uncomfortable tight face masks, gowns and headgear visors resulting in a headache and overheating"), guidance about use was inconsistent ["changing or mixed information at times regarding the need for full PPE (and) advice regarding donning PPE in arrest/ emergency situations"] and concerns about supply chain issues were commonplace.

\section{Contracting COVID-19 and/or transferring to colleagues and family}

A common concern in the responses related to the risk of causing infection, "(I feel) stress associated with risk of exposure but also the stress of possible spreading of the virus to co-workers and patients when asymptomatic".

\section{Structured psychological support}

The need for routine psychological support for staff working in critical care was noted, "(there is) a huge lack of needed support in ICU, regardless of COVID!" There was frequent free-text commentary with suggestions regarding the in-work provision of psychological supports, such as one nurse's, "debriefing on unit; more support in work as opposed to outside of work." Debriefing was a common suggestion for supporting staff's well-being.

\section{Personal}

\section{Response to public recognition}

An interesting cause of stress noted by doctors and nurses was the public perception of health care workers as heroes, "(I am) finding it stressful/embarrassing that people are calling us heroes when I feel like I'm doing nothing to benefit anyone". Others expressed a desire for more practical recognition; "additional PAY would be great. It would be a little more reassuring...than just being tagged as heroes and getting claps".

\section{Stigma to seeking supports}

Respondents expressed concern at being stigmatised for accessing well-being support services. This was explained as "feeling embarrassed to access support/access help", a "natural reluctance for medical professionals to seek emotional/psychological support", "judgement from colleagues that they may think I am not able to cope if I utilised support available" and "the general culture in Irish hospitals".

\section{Financial}

A change in working patterns for trainee doctors has led to reduced income in some centers, with one noting, "(I am) a graduate entry doctor with lots of debt". Several responses described concern about being able to continue mortgage repayments, many due to a partner's loss of income. Longstanding dissatisfaction with pay has been exacerbated, "I believe pay parity with other public service jobs would be a great show of support towards nurses." 


\section{Home-work interface}

\section{Alteration of usual stress-relieving activities and supports}

The disruption to work-life balance was highlighted as "when you can't go out and enjoy yourself on the downtime it makes it worse" and the "loss of social or exercise outlets". People who were able to continue their usual activities seemed to benefit, "Starting the duty with prayer helps a lot to cope with stress", in contrast to those with a major change to their established routine, "I have had to develop a support system external to my normal supports...it's been challenging and not as effective."

\section{Altered interaction with friends/family}

Healthcare workers and support staff noted that they experienced "not being able to see (their) partner", and "separation from young family", highlighting the sacrifices made during this pandemic. Non-Irish respondents had an additional stress from not being able to visit their home country or family. Conversely, a small number noted increased time spent with family members, "this pandemic has brought us all together."

\section{Childcare and accommodation issues}

For many healthcare workers, childcare was a frequently listed cause for added stress. Responses included, "No Childcare. Minding two very small babies at home and then going into an ICU setting to give my all. No downtime. Very, very stressful" Another parent stated, "I feel so upset that I am expected to work in ICU and I have no childcare as crèche is closed. I feel so let-down by the government in this matter". Furthermore, respondents endured the insecurity of rental accommodation, in one case a landlord evicting a healthcare worker because of the risk that "you may import virus into my property".

\section{Uncertainty about the future}

\section{Global illness trajectory}

This pandemic has affected the certainty of the future for the individual, the healthcare system, the country and internationally. One respondent's greatest stressor was "not knowing when I can travel home to see my family". One allied health professional stated they "worry about winter, less reserve, government finances, etc." The tragic international scenes prompted one nurse to respond, "I had huge anxiety about what was going to happen; would we have to deal with overcrowding we had seen in Italy and Spain".

\section{Social interventions}

Concern was expressed about the public not adhering to social restrictions and the impact of this on the community levels of COVID-19, with the attendant effects on staff workload, hospital admissions and ICU capacity.

\section{Government/institutional changes}

The importance of clear, consistent communication was evident as was the stress experienced when this was lacking; "A feeling of 'cognitive overload' seems very common due to changing practice-information on how to best deal with this could be useful." Frequent changes of institutional guidelines were a significant stressor that was noted. The solution was suggested of, "weekly written updates from the COVID ICU team to outline where we are as a service and what plans are being put in place for the next weeks".

\section{Further redeployment to COVID-19 patient care}

Some of our respondents were staff who had been redeployed from non-critical care clinical roles, objected to "being redeployed and having to stay in the ICU when there is more than enough staff, putting everyone in risk".

\section{Discussion}

Our results highlight the issues that matter most to healthcare workers seeking satisfaction and fulfilment at work; these are categorised into themes and subthemes in our results. While many of these issues are likely to be important in any workplace at any time, the pandemic has amplified their importance in the healthcare setting, and in particular in an ICU, where specialised care of the most unwell patients occurs, often under adverse and time-critical circumstances.

From a social perspective, our survey respondents want work in an environment that affords them a sense of belonging, to be integrated in a team that emphasises guidance and education and access to psychological supports without fear of ignominy. They seek reassurance about occupational safety. They want to be recipients of updates and information relevant to their job. These preferences are not unique to our study population, and a lack of these elements in the work environment has been shown to contribute to healthcare worker burnout during the current pandemic (Algunmeeyn et al. 2020). Critical care staff vary in their profession, therapy preferences and personal attributes, but they share a strong a professional identity, and strive to pursue activities 
that are consistent with this self-concept-especially during periods of increased professional demand (Ervin et al. 2018; Yadav et al. 2019). A strong determinant of satisfaction in the workplace relates to justice, the perception by staff that they are being treated fairly. Managers can improve staff perception of organisational justice by concentrating on fair reward, optimising policies and procedures and ensuring good communication and distribution of information (Hashish 2020). It is clear from our study that pandemic-related problems disrupted many of the factors that promote workplace satisfaction.

Our findings concur with an overarching principle of psychological stress, that it occurs as a consequence of the interaction between an individual and their environment. According to this cognitive-relational theory, an environment that is perceived to be excessively onerous or hazardous is one that creates stress in the individual (Lazarus and Folkman 1984). Inter-individual variation is seen in personal responses to such an environment, influenced by factors, such as gender, socioeconomic status, professional role, mental and physical health, personality and social support (Conversano et al. 2020). Experiences of moral distress were evident from responses from all professions in our study; the person specific, workplace specific and external factors that combine to produce conditions in which moral distress develops all increased during the COVID-19 pandemic (Burston and Tuckett 2012). Moral distress has been recognised as an international problem for frontline healthcare workers throughout the 2020 global pandemic (Cacchione 2020; Menon and Padhy 2020).

Our study findings also overlap with more specific models of occupational stress which help explain why pandemic work conditions in an ICU may promote negative psychological outcomes. Three models appear most pertinent to our study: the person-environment fit (PE-Fit) model, the job-demand-control model and work intensification theory.

The PE-Fit model highlights the importance of matching the skills, knowledge, and limitations of a worker with their job and work environment (Tinsley 2000). Increasing discordance between these variables will have a proportionally negative impact on workers' health and psychological well-being. Our survey revealed many of the drivers for increased stress related to the healthcare workers' environment, disrupting the person-environment balance for ICUtrained staff, and to a greater extent, for staff redeployed to the ICU. For managers, this highlights the importance of pre-empting and ameliorating environmental stressors, thereby minimising additional stress for workers (Billings et al. 2020). By taking these actions, managers may contribute to the physical health of their staff; an association between psychological stress and physical symptoms of headache, throat pain, insomnia and joint pain has been found in healthcare workers working during the COVID-19 outbreak (Chew et al. 2020).

The job-demand-control model asserts that occupational well-being is at its lowest when workers have a high workload combined with a low level of control over their work (Karasek 1979). The requirements of healthcare workers to optimise their well-being have been distilled by Shanafelt et al (2020) to "hear me, protect me, prepare me, support me, care for me." For medical and nursing staff deployed to the ICU from other clinical hospital areas, as well as junior ICU-trained healthcare workers, the experience of high work load and low levels of control can be ameliorated by managerial use of this simple framework of support developed by Shanafelt et al. (2020).

Finally, work intensification theory describes the amount of work to be undertaken and the time pressure to complete this work in a fixed period of time; the theory holds that work intensification predicts greater work-life interference, reduced well-being and greater stress for the worker (Fein et al. 2017). This is the backdrop to the findings of our study: a global pandemic of a contagious and lethal virus which meant that obligations, both at home and at work, were increased for many healthcare workers.

In addition to the three established models of occupational stress discussed above, our study highlights two unique aspects of the pandemic that may have exacerbated workers' stress and which do not easily fit traditional models of occupational stress; home-work interface and future uncertainty. Prominent in our findings were extra-organisational factors, which we termed the 'home-work interface'. The COVID-19 pandemic has been characterised by major social changes in the realms of social interaction, family, childcare, accommodation and recreation. These issues at the home-work interface may have had a proportionally larger influence on workers' well-being than would be expected in non-pandemic conditions; increased professional demands were exacerbated by a disruption to social supports, financial stability, family routines and recreational activities.

The final stressor unique to the pandemic was future uncertainty, focused locally (in healthcare workers' workplace or home) as well as broadly on a national and global scale. This uncertainty was expressed as anticipatory anxiety by many of our respondents. To illustrate this novel combination of factors affecting healthcare workers during the COVID-19 pandemic, we have proposed a model of occupational stress (Fig. 1) drawing from existing models and from the unique findings of our study. 
Fig. 1 A model of occupational stress during the COVID-19 pandemic

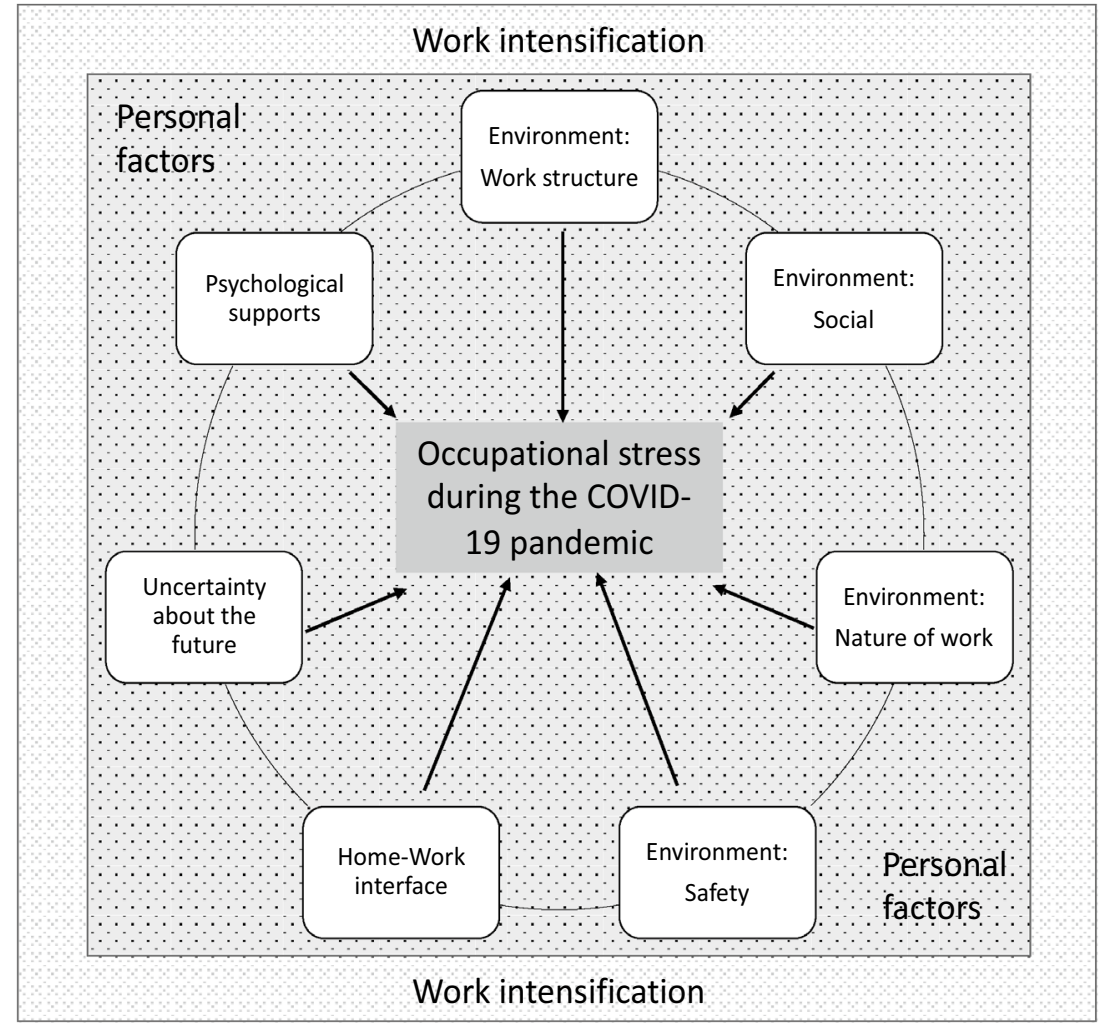

\section{Limitations}

This study was conducted across four clinical sites and included healthcare workers caring for adult and paediatric critical care patients-our results are applicable therefore most accurately to critical care staff. The timing of this survey, which started 2-3 weeks after the peak of intensive care COVID-19 activity may have influenced the responses. However, the adult ICUs continued to have bed occupancies of $>100 \%$ at the time of data collection. All the data for this study were derived from only four free-text questions; follow-up qualitative interviews would have added to the insights gained from the questionnaire. Furthermore, staff who were 'cocooning' at home had no access to work email and could not contribute to the study. On the contrary however, both of these concerns are balanced by a high response rate and a broad representation from the critical care multidisciplinary team of clinical and non-clinical staff.

\section{Conclusion}

Our study findings identified numerous factors contributing to the psychological impact of working in an intensive care setting during the on-going COVID-19 pandemic. The home, work and social environments; personal factors; the home-work interface and uncertainty about the future were the major themes derived from this qualitative study. In large part, the work environment-its structure, the type of work done, and perceptions of safety and interpersonal relationships therein - dictated the emotional and psychological responses of healthcare staff. In addition, the unique nature of the pandemic presented additional stressors to healthcare workers, in particular the effect of societal restrictions on home life. Our survey confirms the theory of Shanafelt et al. (2020) that asking staff about their needs is a simple but effective means of determining what measures can be implemented by management to reduce the burden on healthcare staff. By doing this, we have identified important factors that contribute to occupational stress for healthcare workers working through the on-going COVID-19 pandemic; we believe our proposed model of occupational stress (Fig. 1) which portrays the interplay between these factors can be utilised to aid further research in this area. The findings have been forwarded to the participating clinical sites, and have already been utilised to develop additional psychological supports for the critical care staff. 


\title{
Appendix 1 Survey Questionnaire
}
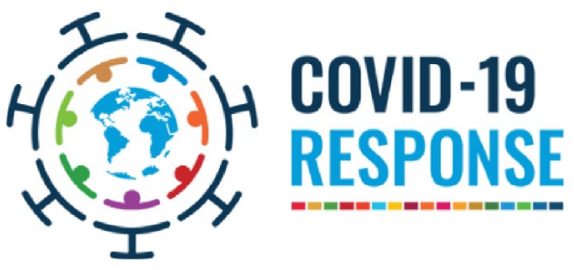

\author{
CRITICAL CARE STAFF WORKING IN THE \\ 2020 PANDEMIC \\ PSYCHOLOGICAL IMPACT OF COVID-19 ON \\ HEALTHCARE STAFF WORKING IN \\ INTENSIVE CARE AND COPING \\ STRATEGIES USED
}

It should take 10 - 15 minutes to complete. If you have any questions about the survey, please contact Robert ffrench-O'Carroll, robffrench@gmail.com

1. I understand that by ticking this box I am confirming my consent to taking part in this survey. I have been provided with a participant information leaflet and I understand that by agreeing to participate the data that I provide will be analysed, and published in an aggregated fashion. I understand that the data that I provide is anonymous; that I cannot be identified at any point. (Please tick to confirm consent)

2. Please be assured that all answers remain $100 \%$ confidential. We would like to create unique participant identifiers in order to compare responses in future surveys.

2.1 What is the first letter of your mother's FIRST name (eg M if Mary)

2.2 How many older brothers (living and deceased) do you have (eg 0 or 1)

2.3 First letter of your middle name (if none use X)

\section{SECTION A: DEMOGRAPHICS AND BACKGROUND}

3. What is your age category?
$\square 20-25$
$\square 31-35$
$\square 41-45$
$\square 46-50$
$\square 51-55$
$56-60$
$\square 60+$
$\square 26-30$
$\square 36-40$
$46-50$

$\square 56-60$

4. Gender

\begin{tabular}{|c|c|c|}
\hline$\square$ Female & $\square$ Male & $\square$ Rather Not Say \\
\hline$\square$ Transgender & $\square$ Intersex & $\begin{array}{l}\square \text { Gender Non- } \\
\text { Conforming }\end{array}$ \\
\hline
\end{tabular}
$\square$ Non Binary
$\square$ Other (please specify),

5. What is your ethnic or cultural background?

$\square$ White British

$\square$ White Irish

$\square$ Any other white background (specify below)

$\square$ Mixed White and Black Caribbean

$\square$ Mixed White and Black African

$\square$ Asian Pakistani
$\square$ Asian Chinese
$\square$ Asian other (specify
below)
$\square$ Black Caribbean
$\square$ Black African


$\square$ Mixed White and Asian

$\square$ Black other (specify

below)

$\square$ Mixed other (specify below)

$\square$ Chinese

$\square$ Asian Indian

$\square$ Other (specify below)

$\square$ Asian Filipino

$\square$ Rather No Say

$\square$ Other ethic

category:

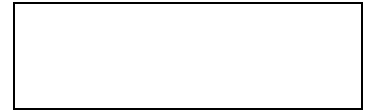

6. Please select your Marital status
$\square$ Single
Married
$\square$ Co-
$\square$ Other (please specify),
habiting

7. Do you have children?

$\square$ Yes, they live with me fulltime or part-time

$\square$ Yes, they do not live with me

$\square$ I live in a home with children who are not my own

$\square$ No

8. Mode of Commute (Please select which you use more frequently)

$\square$ Own Transport $\square$ Public Transport

9. What Hospital are you working in?

$\square$ CHI Crumlin $\square$ CHI Temple

Street

$\square$ St. James

Hospital

Tallaght University

Hospital

10. Your current profession and grade where applicable

Allied Health Professional

$\square$ Clinical Engineer $\square$ Pharmacist $\square$ Physiotherapy
$\square$ Dietician

General Support Staff

$\square$ Health Care $\square$ Porter $\square$ Household/Janitor

Assistance

Management/Admin/Information Communication Technology

$\square$ Administrative $\square$ Ward Clerk

Medical

$\begin{array}{ll}\square \text { Consultant } & \square \text { Fellow } \quad \square \text { Registrar }\end{array}$

Nursing

$\square \mathrm{CNM}$

$\square \mathrm{CNEF} \quad \square$ Staff Nurse

$\square$ Other (please specify), 
11. Have you been deployed to ICU from another clinical area because of the COVID-19 Pandemic?

$\square$ YES $\square$ NO

If 'YES', please specify what area deployed from, e.g. theatre/ infant ward/ Day Care/ etc.

-

12. How long have you worked in intensive care units?

\begin{tabular}{|c|c|c|c|}
\hline$\square 3$ months & $\square 1$ years & $\square 11-15$ years & $\square 26-30$ years \\
\hline 6 months & $\square 2-5$ years & $\square 16-20$ years & $\square>31$ years \\
\hline 9 months & $\square 6-10$ years & $\square 21-25$ years & $\square$ Other (please specify), \\
\hline
\end{tabular}

13. How many hours a) do you usually work per week and b) have you worked in the last week?

13.1 Usual hours worked per week

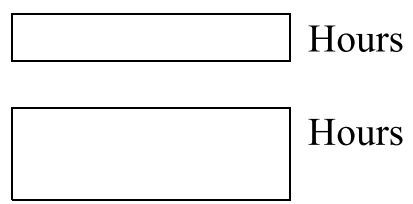

13.2 Number of hours worked in the last week

14. Have you had to pick up extra shifts within the last week due to colleagues being ill?

$\square$ YES $\square$ NO

15. How many patients with suspected COVID-19 have you been involved in the care of?
$\square$ Non

$$
\square 1-5
$$
$6-10$
$\square 11-15$
$\square$ 16-20
$\square 20-40 \quad \square>40$

16. How many patients with confirmed COVID 19 have you been involved in the care of?
$\square$ None

$$
1-5
$$$$
\square 6-10
$$$$
\square 11-15
$$
$\square 16-20$
$\square 20-40 \quad \square>40$

17. During the course of the current coronavirus pandemic, have you been quarantined for an infection or close contact?
$\square$ YES
$\square$ NO

18. Do you feel you have received adequate training in personal protective equipment use?
$\square$ YES

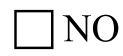

19. In what form was training you received?

Department or hospital lecture

One on one session

$\square$ Simulation training

Video instruction
$\square$ No training in PPE received
$\square$ Other (please specify),

SECTION B: MORAL DISTRESS \& PSYCHOLOGICAL WELLBEING

\section{Moral Distress for Healthcare Professionals (MMD-HP) Scale}


Moral distress occurs when professionals cannot carry out what they believe to be ethically appropriate actions because of constraints or barriers. With relation to the current COVID-19 pandemic please select how frequently you have experienced the below situations and the level of distress they caused. If you have not experienced a situation please indicate the level of distress you would experience if it occurred in your practice.

Please rank the FREQUENCY and LEVEL OF DISTRESS with which you have experienced the following.

$\begin{array}{llll} & \text { FREQUENCY } & & \text { LEVEL OF DISTRESS } \\ 0 & \text { Never } & 0 & \text { None } \\ 1 & \text { Rarely } & 1 & \text { Occasional distressing } \\ 2 & \text { Every once a while } & 2 & \text { Neutral } \\ 3 & \text { Sometimes } & 3 & \text { Somewhat distressing } \\ 4 & \text { Very frequently } & 4 & \text { Very distressing }\end{array}$

\section{Q1 MORAL DISTRESS SCALE}

\section{FREQUEN DISTRES} $\underline{\mathrm{CY}} \quad \underline{\mathrm{S}}$

20.1 Be required to care for more patients than I can $\begin{array}{llllllllll}0 & 1 & 2 & 3 & 4 & 0 & 1 & 2 & 3 & 4\end{array}$ safely care for.

20.2 Experience compromised patient care due to lack $\quad \begin{array}{llllllllll}0 & 1 & 2 & 3 & 4 & 0 & 1 & 2 & 3 & 4\end{array}$ of resources/equipment/ bed capacity.
20.3 Be required to care for patients whom I do $\begin{array}{llllllllll}0 & 1 & 2 & 3 & 4 & 0 & 1 & 2 & 3 & 4\end{array}$ not feel qualified to care for.

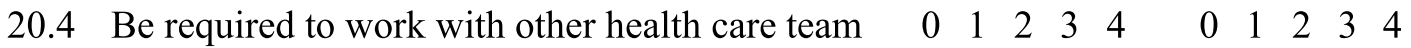 members who are not as competent as patient care requires.

\section{PSYCHOLOGICAL WELLBEING}

Please consider the following reactions which sometimes occur after a traumatic event. This questionnaire is concerned with your personal reactions to the current COVID-19 pandemic. Please indicate whether or not you have experienced any of the following $0-$ No (or less than twice in past week)

1 - Yes, at least twice in past week

\section{Q TRAUMA SCREENING QUESTIONNAIRE}

21.1 Upsetting thoughts or memories about the event that have come FREQUENCY into your mind against your will

21.2 Upsetting dreams about the event

21.3 Acting or feeling as though the event were happening again

21.4 Feeling upset by reminders of the event 
21.5 Bodily reactions (such as fast heartbeat, stomach churning,

$0 \quad 1$ sweatiness, dizziness) when reminded of the event

21.6 Difficulty falling or staying asleep

$\begin{array}{ll}0 & 1\end{array}$

21.7 Irritability or outbursts of anger

21.8 Difficulty concentrating

$0 \quad 1$

21.8 Heightened awareness of potential dangers to yourself and $0 \quad 1$ others

21.9 Being jumpy or being startled at something unexpected

$0 \quad 1$

22. With regards to the current Covid-19 pandemic, how would you rate your level of stress regarding the prospect of the following scenarios arising?'

1 No stress

2 Mild stress

3 Moderate stress

4 Much Stress

5 Extreme Stress

NA Not applicable

\section{Q COVID-19 PANDEMIC}

22.1 Shortage of ICU beds

22.2 Shortage of healthcare staff

22.3 Shortage of personal protective equipment

22.4 Shortage of equipment (ventilators/oxygen etc)

22.5 Becoming ill with COVID-19

22.6 Passing coronavirus to family and friends

22.7 Being forced to work excessive hours

22.8 Being redeployed to different clinical area or different hospital

22.9 Being discriminated by own colleagues if contracted COVID-19

22.10 Unable to travel to work by public transport

22.11 Fear of financial instability if contracted COVID-19

22.12 Treating patients outside my trained role (e.g. treating adults in paediatric hospital)
LEVEL OF

STRESS

$\begin{array}{llllll}1 & 2 & 3 & 4 & 5 & \mathrm{NA}\end{array}$

$\begin{array}{llllll}1 & 2 & 3 & 4 & 5 & \mathrm{NA}\end{array}$

$\begin{array}{llllll}1 & 2 & 3 & 4 & 5 & \mathrm{NA}\end{array}$

$\begin{array}{llllll}1 & 2 & 3 & 4 & 5 & \mathrm{NA}\end{array}$

$\begin{array}{llllll}1 & 2 & 3 & 4 & 5 & \mathrm{NA}\end{array}$

$\begin{array}{llllll}1 & 2 & 3 & 4 & 5 & \mathrm{NA}\end{array}$

$\begin{array}{llllll}1 & 2 & 3 & 4 & 5 & \mathrm{NA}\end{array}$

$\begin{array}{llllll}1 & 2 & 3 & 4 & 5 & \mathrm{NA}\end{array}$

$\begin{array}{llllll}1 & 2 & 3 & 4 & 5 & \mathrm{NA}\end{array}$

$\begin{array}{llllll}1 & 2 & 3 & 4 & 5 & \mathrm{NA}\end{array}$

$\begin{array}{llllll}1 & 2 & 3 & 4 & 5 & \mathrm{NA}\end{array}$

$\begin{array}{llllll}1 & 2 & 3 & 4 & 5 & \mathrm{NA}\end{array}$

23. Are there any other factors related to the current crisis causing you stress currently?

\section{SECTION C: COPING STRATEGIES OF HEALTHCARE WORKERS}

24. BriefCOPE; Do you use any of the following coping strategies to help you deal with your current stress?

1 I haven't been doing this at all 
2 A little bit

3 Sometimes

4 I've been doing this a lot

\section{Q BriefCOPE}

24.1 I've been turning to work or other activities to take my mind off things.

24.2 I've been concentrating my efforts on doing something about the situation I'm in.

24.3 I've been saying to myself "this isn't real".

$\begin{array}{llll}1 & 2 & 3 & 4\end{array}$

24.4 I've been using alcohol or other drugs to make myself feel better

$\begin{array}{llll}1 & 2 & 3 & 4\end{array}$

24.5 I've been getting emotional support from others.

$\begin{array}{llll}1 & 2 & 3 & 4\end{array}$

24.6 I've been giving up trying to deal with it.

$\begin{array}{llll}1 & 2 & 3 & 4\end{array}$

24.7 I've been taking action to try to make the situation better.

$\begin{array}{llll}1 & 2 & 3 & 4\end{array}$

24.8 I've been refusing to believe that it has happened.

$\begin{array}{llll}1 & 2 & 3 & 4\end{array}$

24.9 I've been saying things to let my unpleasant feelings escape.

$\begin{array}{llll}1 & 2 & 3 & 4\end{array}$

24.10 I've been getting help and advice from other people.

$\begin{array}{llll}1 & 2 & 3 & 4\end{array}$

24.11 I've been using alcohol or other drugs to help me get through it.

$\begin{array}{llll}1 & 2 & 3 & 4\end{array}$

24.12 I've been trying to see it in a different light, to make it seem more

$\begin{array}{llll}1 & 2 & 3 & 4\end{array}$ positive.

24.13 I've been criticizing myself.

$\begin{array}{llll}1 & 2 & 3 & 4\end{array}$

24.14 I've been trying to come up with a strategy about what to do.

$\begin{array}{llll}1 & 2 & 3 & 4\end{array}$

24.15 I've been getting comfort and understanding from someone.

$\begin{array}{llll}1 & 2 & 3 & 4\end{array}$

24.16 I've been giving up the attempt to cope.

$\begin{array}{llll}1 & 2 & 3 & 4\end{array}$

24.17 I've been looking for something good in what is happening.

$\begin{array}{llll}1 & 2 & 3 & 4\end{array}$

24.18 I've been making jokes about it.

$\begin{array}{llll}1 & 2 & 3 & 4\end{array}$

24.19 I've been doing something to think about it less, such as going to movies, watching TV, reading, daydreaming, sleeping, or shopping.

24.20 I've been accepting the reality of the fact that it has happened.

$\begin{array}{llll}1 & 2 & 3 & 4\end{array}$

24.21 I've been expressing my negative feelings.

$\begin{array}{llll}1 & 2 & 3 & 4\end{array}$

24.22 I've been trying to find comfort in my religion or spiritual beliefs.

$\begin{array}{llll}1 & 2 & 3 & 4\end{array}$

24.23 I've been trying to get advice or help from other people about what

$\begin{array}{llll}1 & 2 & 3 & 4\end{array}$

24.24 I've been learning to live with it.

$\begin{array}{llll}1 & 2 & 3 & 4\end{array}$

24.25 I've been thinking hard about what steps to take.

$\begin{array}{llll}1 & 2 & 3 & 4\end{array}$

24.26 I've been blaming myself for things that happened

$\begin{array}{llll}1 & 2 & 3 & 4\end{array}$

24.27 I've been praying or meditating

$\begin{array}{llll}1 & 2 & 3 & 4\end{array}$

24.28 I've been making fun of the situation.

25. Which supports are most helpful for healthcare staff during this time? (Can choose more than one) 
Psychological support - face to face or telephone counselling

Employee Assistance Programme

Occupational Health

Your General practitioner

Mindfulness or Resilience training

Online resources such as mindthefrontline.com

Departmental debriefs of critical events

Informal debriefs of events with peers

Hospital App to provide general regular staff updates and information directly to you

COVID-19 helpline for health care staff 1850420420

COVID-19 Specific clinical Training

Being allocated to Non COVID duties for intervals

Resources from training bodies (eg fight fatigue from Association of Anaesthetists)

Public recognition - such as feed the heroes campaign

Other - please specify

26. Are there any barriers or obstacles to making use of available supports?

27. What other supports would you or your colleagues benefit from but are currently not provided?

\section{Do you have any other comments/ information about your experiences you would like to share?}

We really appreciate your feedback and will use the results to improve current services for the future. Thank You!

\begin{abstract}
Acknowledgements We thank the clinical and non-clinical staff of the four participating critical care units; Tallaght University Hospital, Dublin; St. James' Hospital, Dublin; Our Lady's Children's Hospital Crumlin, Dublin; Temple Street Children's Hospital. Particular thanks to Dr. Enda O'Connor who provided untiring support for the project. The authors would also like to acknowledge the following individuals who have made substantial contributions to the study but who do not fulfil requirements for authorship; S. Crowe, A. Fahy, L. Dunne, D. Hughes, E. Gordon, D. Doyle, S. Delaney.
\end{abstract}

Funding No funding was received for conducting this study.

Data availability Original questionnaire is attached as "Appendix 1". Full excel spreadsheet of all responses available on request, with modifications to protect the identity of respondents.

\section{Compliance with ethical standards}

Conflicts of interest The authors have no conflicts of interest to declare that are relevant to the content of this article.

Ethics approval Ethical approval for the study was granted by the Irish National Research Ethics Committee governing research for COVID-19 related studies (20-NREC-COV-005).

Consent to participate All questionnaire respondents gave written consent to participate.

Consent for publication All authors give consent for publication.

Code availability Not applicable. 


\section{References}

Algunmeeyn A, El-Dahiyat F, Altakhineh M et al (2020) Understanding the factors influencing healthcare providers' burnout during the outbreak of COVID-19 in Jordanian hospitals. J Pharm Policy Pract 13:53. https://doi.org/10.1186/s40545-020-00262-y

An Roinn Sláinte (2018) Health service capacity review 2018 executive report. Review of health demand and capacity requirements in Ireland to 2031. https://assets.gov.ie/10131/5bb5ff12463345b bac465aaf02a2333d.pdf. Accessed 10 Jul 2020

Billings J, Greene T, Kember T, Grey N et al (2020) Supporting hospital staff during COVID-19: early interventions. Occup Med 70(6):453. https://doi.org/10.1093/occmed/kqaa121

Brooks S, Gerada C, Chalder T (2011) Review of literature on the mental health of doctors: are specialist services needed? J Ment Health 20:146-156. https://doi.org/10.3109/09638237.2010.541300

Burston A, Tuckett A (2012) Moral distress in nursing: contributing factors, outcomes and interventions. Nurs Ethics 20(3):312-324. https://doi.org/10.1177/0969733012462049

Cacchione P (2020) Moral distress in the midst of the COVID19 pandemic. Clin Nurs Res 29(4):215-216. https://doi. org/10.1177/1054773820920385

Chew N, Lee G, Tan B et al (2020) A multinational, multicentre study on the psychological outcomes and associated physical symptoms amongst healthcare workers during COVID-19 outbreak. Brain Behav Immun 88:559-565. https://doi.org/10.1016/j. bbi.2020.04.049

Conversano C, Marchi L, Miniati M (2020) Psychological distress among healthcare professionals involved in the COVID-19 emergency: vulnerability and resilience factors. Clin Neuropsychiatry 17(2):94-96. https://doi.org/10.36131/CN20200212

Cook T (2020) Risk to health from COVID-19 for anaesthetists and intensivists-a narrative review. Anaesthesia 75(11):1494-1508. https://doi.org/10.1111/anae.15220

University College London (2020) Coping with coronavirus. Self help guides. https://www.copingwithcoronavirus.co.uk/self-help-guide s.html. Accessed 10 Aug 2020

Ervin J, Kahn J, Cohen T, Weingart L (2018) Teamwork in the intensive care unit. Am Psychol 73(4):468-477. https://doi.org/10.1037/ amp0000247

Fein E, Skinner N, Machin M (2017) Work intensification, work-life interference, stress, and well-being in Australian workers. Int Stud Manag Organ 47(4):360-371. https://doi.org/10.1080/00208 825.2017.1382271

ffrench-O'Carroll R, Feeley T, Tan MH, Magner C, L'Estrange K, Efrimescu C-I, O'Connor E, Lyons B, Crowe S, Delaney S (2020) Psychological impact of COVID-19 on staff working in paediatric and adult critical care. Br J Anaesth. https://doi.org/10.1016/j. bja.2020.09.040

Gerada C (2008) The practitioner health programme: a free and confidential health service for doctors and dentists in London. London J Prim Care 1(2):74-77. https://doi.org/10.1080/17571 472.2008.11493212

Greenberg N, Docherty M, Gnanapragasam S, Wessely S (2020) Managing mental health challenges faced by healthcare workers during COVID-19 pandemic. BMJ 368:m1211. https://doi.org/10.1136/ bmj.m1211

Hashish E (2020) Nurses' perception of organizational justice and its relationship to their workplace deviance. Nursing Ethics 27(1):273-288. https://doi.org/10.1177/0969733019834978

Heath C, Sommerfield A, von Ungern-Sternberg B (2020) Resilience strategies to manage psychological distress among healthcare workers during the COVID-19 pandemic: a narrative review.
Anaesthesia 75(10):1364-1371. https://doi.org/10.1111/ anae. 15180

Highfield J (2020) Advice for sustaining staff wellbeing in critical care during and beyond COVID-19. Intensive care society. https ://www.practitionerhealth.nhs.uk/media/content/files/Sustaining \%20wellbeing\%20COVID19.pdf. Accessed 13 Aug 2020

Hignett S, Welsh R, Banerjee J (2020) Human factors issues of working in personal protective equipment during the COVID-19 pandemic. Anaesthesia 76(1):134-135. https://doi.org/10.1111/anae.15198

Hsieh H-F, Shannon S (2005) Three approaches to qualitative content analysis. Qual Health Res 15(9):1277-1288. https://doi. org/10.1177/1049732305276687

Huremović D (2019) Brief history of pandemics (pandemics throughout history). In: Huremović D (ed) Psychiatry of pandemics. A mental health response to infection outbreak. Springer International Publishing, New York, pp 7-35

IMO (2020) Opening Remarks to Special Committee on COVID-19. https://www.imo.ie/news-media/news-press-releases/2020/imoopening-remarks-to-sp/index.xml. Accessed $10 \mathrm{Jul} 2020$

Intensive Care Society (2020) Intensive Care Society: wellbeing and psychological resource library. https://www.ics.ac.uk/ICS/ICS/ Wellbeing_resources.aspx. Accessed 2 Jan 2021

Karasek R (1979) Job demands, job decision latitude, and mental strain: implications for job redesign. Adm Sci Q 24(2):285-308. https://doi.org/10.2307/2392498

Lazarus R, Folkman S (1984) Stress, appraisal, and coping. Springer Publishing Company, New York

Liu S, Yang L, Zhang C, Xiang Y et al (2020) Online mental health services in China during the COVID-19 outbreak. Lancet Psychiatry 7(4):e17-e18. https://doi.org/10.1016/S2215-0366(20)30077-8

Menon V, Padhy S (2020) Ethical dilemmas faced by health care workers during COVID-19 pandemic: issues, implications and suggestions. Asian J Psychiatr 51:102116. https://doi.org/10.1016/j. ajp.2020.102116

Shanafelt T, Ripp J, Trockel M (2020) Understanding and addressing sources of anxiety among health care professionals during the COVID-19 pandemic. JAMA 323(21):2133-2134. https://doi. org/10.1001/jama.2020.5893

Shelton C, Smith A, Mort M (2014) Opening up the black box: an introduction to qualitative research methods in anaesthesia. Anaesthesia 69(3):270-280. https://doi.org/10.1111/anae.12517

Sorbello M, El-Boghdadly K, Di Giacinto I et al (2020) The Italian coronavirus disease 2019 outbreak: recommendations from clinical practice. Anaesthesia 75(6):724-732. https://doi.org/10.1111/ anae. 15049

Teti M, Schatz E, Liebenberg L (2020) Methods in the time of COVID19: the vital role of qualitative inquiries. Int J Qual Methods 19:15. https://doi.org/10.1177/1609406920920962

Tinsley H (2000) The congruence myth: an analysis of the efficacy of the person-environment fit model. J Vocat Behav 56(2):147-179. https://doi.org/10.1006/jvbe.1999.1727

Williams R, Murray E, Neal A, and Kemp V (2020). The top ten messages for supporting healthcare staff during the COVID-19 pandemic. Royal College of Psychiatrists. https://www.rcpsych.ac. uk/docs/default-source/about-us/covid-19/top-ten-messages-willi ams-et-al.pdf?sfvrsn=990e3861_0. Accessed 10 Aug 2020

World Health Organisation (2020) WHO Director-General's opening remarks at the media briefing on COVID-19-11 March 2020. https://www.who.int/director-general/speeches/detail/who-direc tor-general-s-opening-remarks-at-the-media-briefing-on-covid -19---11-march-2020. Accessed 20 Aug 2020

Yadav K, Josephs M, Gabler N, Detsky M, Halpern S, Hart J (2019) What's behind the white coat: potential mechanisms 
of physician-attributable variation in critical care. PLoS ONE 14(5):e0216418. https://doi.org/10.1371/journal.pone.0216418

Zhang W, Wang K, Yin L (2020) Mental health and psychosocial problems of medical health workers during the COVID-19 epidemic in China. Psychother Psychosom 89(4):242-250. https://doi. org/10.1159/000507639
Zhu N, Zhang D, Wang W et al (2020) A novel coronavirus from patients with pneumonia in China, 2019. N Engl J Med 382:727733. https://doi.org/10.1056/NEJMoa2001017

Publisher's Note Springer Nature remains neutral with regard to jurisdictional claims in published maps and institutional affiliations. 